\title{
AC 2008-2163: A FIRST YEAR SEMINAR FOR SURVEYING ENGINEERING STUDENTS AND THE EFFECTS ON RETENTION
}

\section{Thomas Seybert, Pennsylvania State University - Wilkes-Barre}

Thomas A. Seybert is Associate Professor of Engineering at The Pennsylvania State Univeristy, Wilkes-Barre Campus. He teaches surveying measurements, stormwater management, and land development design in the surveying program. He is the author of Stormwater Management for Land Development (Wiley, 2006). Address: Penn State Wilkes-Barre, P.O. Box PSU, Lehman, PA, 18627; e-mail:tseybert@psu.edu. 


\title{
A First Year Seminar for Surveying Engineering and the Effects on Retention
}

\begin{abstract}
A first-year seminar for surveying students in the college of engineering was added to the surveying engineering curriculum in 1998. The course is used to introduce students to college academics, the scholarly community, and the surveying profession. Class sizes are limited to 20 students in order to keep the student-teacher ratio low and provide the students an opportunity to make friends with 19 other students in their major. Team exercises are used in several elements of the course. One of the purposes of the course is to build a comfortable academic relationship between the first-semester surveying student and a full-time faculty member in the surveying program. A broader goal of the seminar is to improve student retention from the first year to the second year. This paper presents the topical outline of the first-year seminar and describes a few team exercises that have been well received by the students. Retention rates of first-year surveying students before and after the course was implemented are compared.
\end{abstract}

\section{Introduction}

Penn State University introduced a first-year seminar (FYS) requirement in the Fall 1999 semester for all baccalaureate students within the university. The seminar is mandated to have academic content, be taught by full-time faculty with at least three years of continuous teaching experience at Penn State University, and have a maximum class size of 20 students. The surveying program faculty designed a first-year seminar specifically for surveying majors and taught by surveying faculty (Seybert, et al. ${ }^{4}$ ). The original structure of the course focused mainly on building a strong sense of community among the surveying students while using group exercises to develop collaborative learning and team skills. (Seybert ${ }^{5}$ ) The course is used to compliment topics covered in the first-semester plane surveying course, but also to present skills and information that will increase the chances for academic success. The course is designed around four general areas: (1) academic learning and understanding, (2) essential academic skills, (3) academic support, and (4) the surveying profession.

Academic learning and understanding sessions include a "Meet Your Advisor" exercise, learning styles assessment; and discussions on diversity, civility, and academic integrity. Essential academic skills sessions include a mathematics review, critical thinking, collaborative learning, basic team skills, and problem solving. Academic support sessions usually include a treasure hunt for academic success, overview of surveying program curriculum requirements and course scheduling, team study sessions on plane surveying methods and concepts that are critical for first-year surveying students, using Penn State University's Intranet academic and advising resources, and an introduction to library services and research methods. Exposure to the surveying profession is accomplished through invited speakers from industry who deliver seminars on specialized topics of surveying practice or professional ethics. 
Objectives of the course include building personal connections between surveying students and a full-time surveying faculty member, building a sense of community among peer students, and developing team skills. Entrance to the surveying engineering major at Penn State University is very different than entrance to other engineering majors. Most engineering students are accepted in their major during the first semester of their third year. Surveying engineering students are admitted to the university directly into the surveying engineering major in the first semester. Therefore, a broader objective of the first-year seminar is improving student retention in the surveying program from the first to the second year.

Outcomes for the course state that upon completion students will be able to:

- Identify each class member by first and last name

- Find their academic advisor and schedule an advising meeting

- Understand learning styles and determine their own dominant style of learning.

- Use critical thinking and team skills to complete tasks and solve basic surveying problems.

- Find the location of several student service offices on campus and have a basic understanding of the services offered by each

- Use the Penn State University Intranet to schedule classes, retrieve transcripts, and perform a degree audit.

\section{Structure of the First-Year Seminar}

The course is 15 weeks long, meeting once per week for a two-hour period. Usually only one of the two hours is needed for the weekly meeting (which is the university norm). However, a double period is scheduled for those weeks where team exercises require more than one hour to complete. In general, each meeting has two activities; a short five to ten minute individual exercise, followed by a team exercise. Some weeks students are assigned homework exercises such as meet your advisor, class name-game study, and time management. Table 1 shows a list of topics used in the Fall 2007 offering of the course. Most activities are assigned and completed during the class meeting. Course grades are determined by weighting individual scores $(40 \%)$ and team scores $(60 \%)$. The weighting requires students to be successful at team activities if they wish to get a good grade in the course.

\section{Getting to Know Each Other}

In the first class meeting, the professor introduces a three-minute name game similar to that proposed by Landis, et al. ${ }^{2}$ Each student is asked to introduce them self to another classmate. The student pair is required to discover three items about each other: full name, hometown, and favorite hobbies. Three to four minutes is provided to complete the task. Using the class list, each student is called by name and asked to introduce their "new-found friend," giving full name, hometown, and favorite hobbies. During the introduction, the professor does two things. First, the newly introduced student is welcomed to the class and given a prepared name tent. Then, their name, hometown, and hobbies are recorded on the classroom white board. By the time all students are introduced, each student has a name tent on their desk and the board is filled with names, hometowns and hobbies. Common interests among the students are quickly identified and this often leads to further conversations during and immediately following class among the students. In a class of 15 students this exercise requires about 20 minutes. This simple 
exercise gives each student the opportunity to talk with another student in their major, present information to class mates, and possibly find a person in the class who has similar interests.

Table 1. Outline of Topics and Exercises for the First-Year Seminar

\begin{tabular}{|c|c|}
\hline Week & Topic and Exercise \\
\hline 1 & $\begin{array}{l}\text { Name game; team orientation and organization } \\
\text { Team Exercise I: Reading and Reviewing Professional Literature }\end{array}$ \\
\hline 2 & $\begin{array}{l}\text { Team name game; Meet Your Advisor exercise } \\
\text { Team Exercise II: Trigonometry and Geometry Review }\end{array}$ \\
\hline 3 & $\begin{array}{l}\text { Class name game/name game challenge; learning style assessment exercise } \\
\text { Team Exercise III: Measurement of a Land Parcel }\end{array}$ \\
\hline 4 & $\begin{array}{l}\text { Community service project: Student Government Haunted Forest Benefit } \\
\text { Team Exercise IV: Class Name-Game Challenge Quiz }\end{array}$ \\
\hline 5 & $\begin{array}{l}\text { SUR } 111 \text { Exam } 1 \text { review } \\
\text { Team Exercise V: Solving Basic Survey Problems } 1\end{array}$ \\
\hline 6 & $\begin{array}{l}\text { Diversity, civility, and academic integrity discussion } \\
\text { Time management exercise }\end{array}$ \\
\hline 7 & $\begin{array}{l}\text { Academic survival: tutoring, advising, and counseling services. } \\
\text { Team Exercise VI: Treasure Hunt for Academic Survival }\end{array}$ \\
\hline 8 & $\begin{array}{l}\text { Seminar I: Speaker from industry } \\
\text { All surveying students and faculty invited }\end{array}$ \\
\hline 9 & $\begin{array}{l}\text { Know your academic program; create a course schedule for Spring semester } \\
\text { Team Exercise VII: Know Your Academic Program }\end{array}$ \\
\hline 10 & $\begin{array}{l}\text { SUR } 111 \text { Exam } 2 \text { review } \\
\text { Team Exercise VIII: Solving Basic Survey Problems } 2\end{array}$ \\
\hline 11 & $\begin{array}{l}\text { Seminar II: Speaker from industry } \\
\text { All surveying students and faculty invited }\end{array}$ \\
\hline 12 & $\begin{array}{l}\text { Campus service project } \\
\text { Team Exercise IX: Campus Parking Survey }\end{array}$ \\
\hline 13 & $\begin{array}{l}\text { Seminar III: Speaker from industry } \\
\text { All surveying students and faculty invited }\end{array}$ \\
\hline 14 & $\begin{array}{l}\text { SUR } 111 \text { Final exam review } \\
\text { Team Exercise X: Basic Survey Problems } 3\end{array}$ \\
\hline 15 & $\begin{array}{l}\text { Course summary } \\
\text { Final team scores and pizza party }\end{array}$ \\
\hline
\end{tabular}

At the end of the first day of class, each student is asked to momentarily pose for a photograph with their name tent held in front of them. The professor uses the pictures between the first and second class meeting to memorize the student names. Therefore, for the remainder of the semester, the professor is able to call on any student by first name. This is a very effective technique for establishing a quick personal connection with first-year students. 
In the second week of class, the team name game is implemented. The class is divided into teams of four to five students and each team member is assigned the following tasks: (1) establish a team name and (2) learn the name and hometown of each member of their team. The teams are sent to three separate areas in the classroom building with fifteen minutes to complete the tasks. Upon returning to the classroom, one person from each team is arbitrarily chosen to introduce their team members with hometowns to the rest of the class. Written notes are not allowed. This first team exercise is scored based upon the success of the arbitrarily chosen team member. Team points are assigned accordingly.

In the third week of class, a team challenge is established to have every member of their team able to identify all members of the class by first and last name. As an incentive for meeting the class goal, a quiz is announced for the $4^{\text {th }}$ week of the class, where every student is required to write down the first and last name of all students in the class, using a classroom seating chart filled with the photographs taken on the first day of class. An example of the quiz sheet is shown in Figure 1.

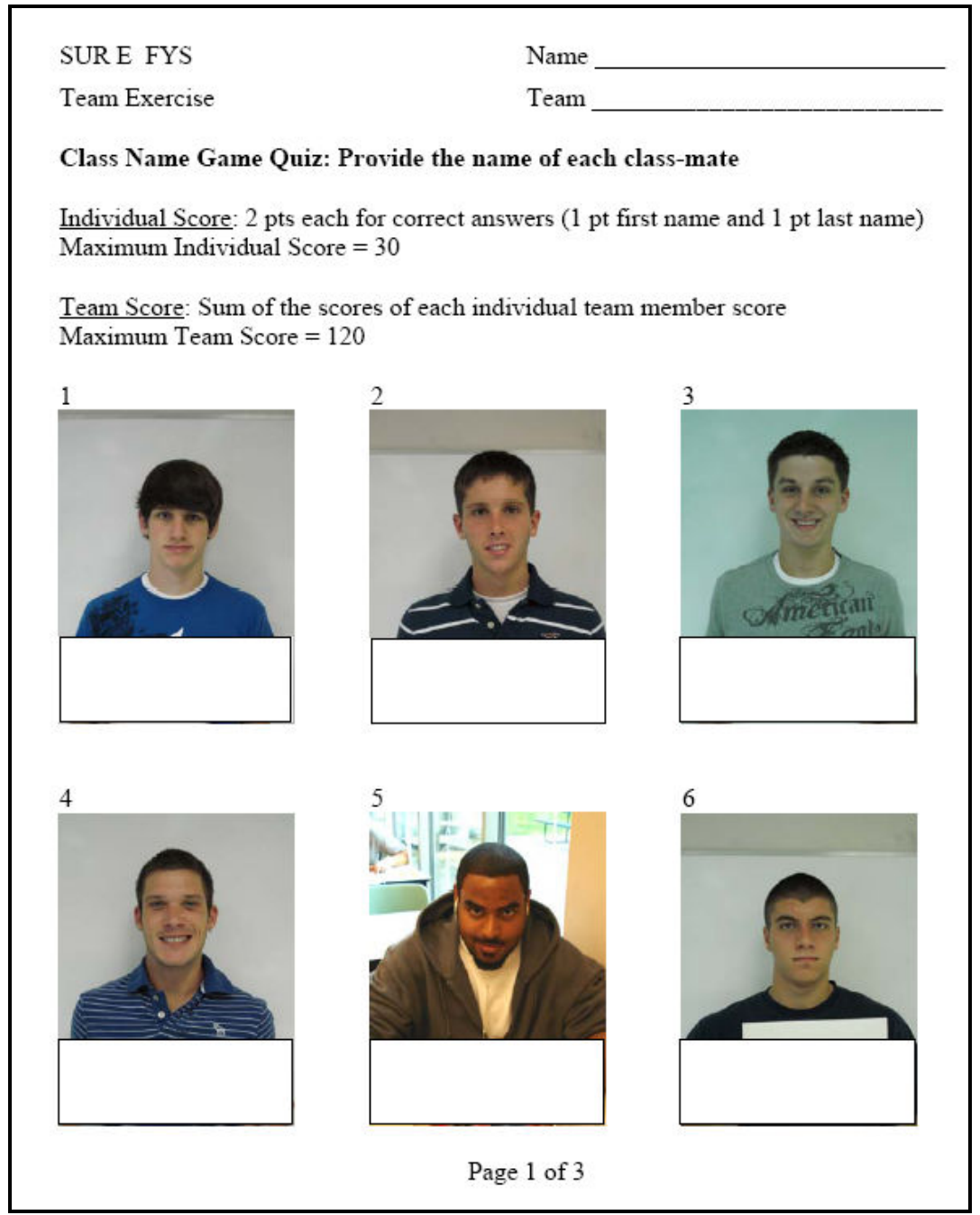

Figure 1. Sample quiz page for Class Name Game Challenge team exercise 
As a study aid, the instructor posts the pictures on the course web-site. Team scores are compiled by counting the number of correct responses for each team member. For example, in a class of fifteen students, with four member teams, the maximum team score would be two points per classmate, times fifteen, times four members per team for a total possible score of 120 points.

\section{Team Exercises}

Several team exercises are used in the first-year seminar. As shown in Table 1, there are ten scheduled team exercises. Of these, four are related to basic mathematic skills necessary for the solution of common problems in plane surveying.

The first mathematics skills exercise is a review of trigonometry and geometry skills that the students should have had in high school. It serves to identify students who need remedial work in order to be successful in the plane surveying course. The professor can quickly relay this information to the plane surveying course instructor because they are always in close contact. The other three mathematics skills courses are problem review sessions scheduled the week prior to a major exam in the plane surveying class. Problem sets are solved by teams with solutions presented by each team to the class. These four sessions are very popular with the students. Of the remaining six team exercises, three are observed to generate the most interest and are performed with the most enthusiasm.

\section{$\underline{\text { Treasure Hunt for Academic Success }}$}

This team exercise consists of a search of the campus for offices that provide important academic support services. These offices include:

- Academic Advising Center

- Learning Center

- Registrar

- Information Technology Services

- Personal Counseling

- Career Counseling

A few days prior to the exercise, I visit each of these offices and coordinate the details of the treasure hunt with the staff person in charge of each area. I place a wall-hanging envelope, marked "SUR 100S Treasure Hunt." Each envelope contains "information sheets" on each area that describes the student services provided by the office. This past year, I simply printed the home page of the Web site for each office on blue sheets of paper, and made them the information sheet. I also asked each office staff person to make available additional information sheets that they typically provide to students who seek services from their office.

At the beginning of the class period, the overall concept and rules of the treasure hunt are described briefly by the instructor. However, successful execution of the exercise depends on reading and following a set of written instructions. Each team is provided with a sealed 9" by 12" envelope containing instructions for the treasure hunt and data tally sheets for each team member. Once the sealed envelopes are opened, the treasure hunt begins. Each team member is provided with an empty 9" by 12 " envelope with their name and team name on it. The envelope 
is used by the student to submit their treasure hunt collection to the instructor at the end of the exercise. Each team member must complete all elements of the treasure hunt for team success.

The objective is to find and visit the six student service offices. The teams are given the building and room number of each location. The task of each member of the team is to (1) go to the area of the student service office, (2) find the wall-hanging envelope marked "SUR 100S Treasure Hunt" and secure a blue sheet, (3) determine the name of the person in charge of the office from the office staff person, and (4) obtain any additional printed information about the office provided in pamphlet or paper hand-out form. After the treasure hunt is completed, each student must organize their tally sheet, collected blues sheets, and additional information sheets in a prescribed order. The teams must assemble the individual student packages into one team package. Points are given for blue sheets, extra information sheets, and correct compilation of accumulated data. Each team must arrive at the check-in station as a group, submitting their team package for evaluation. The instructor determines an optimal time to complete the treasure hunt by performing a trial-run on the day prior to the exercise. This time is not revealed to the teams, but they are aware that the closer they come to the optimal time, the more bonus points the team receives for their effort.

The atmosphere of timed competition usually gets the students charged, and team interaction begins almost immediately. It can be fun to simply watch them execute the hunt. At the end of the exercise, no matter how they place time wise, they will have an organized package of information that describes important student services provided by the campus, plus they will know where to go and whom to see to receive these services.

\section{Measurement of a Land Parcel}

Shortly after the first-year students complete a pace calibration exercise in the plane surveying course, the teams are assigned an exercise of measuring a land parcel. The teams must measure the area of a four-side polygon. The exercise is held on the practice field outside the engineering and technology building as show in Figure 2. Four permanent survey monuments (1A, 2A, 8A, and 9A) are used as the parcel corners. Teams are awarded points for closeness to the known values for each measured line and also for closeness to the know area of the parcel. No surveying equipment is provided for their use. Most teams quickly realize that pacing is their only option. However, how to go about the measurement such that they are confident of the answer is not as obvious. Students must apply what they learned in the trigonometry review exercise in the seminar class, and also what they learned in the plane surveying course with respect to repeated measurements and pacing techniques.

\section{$\underline{\text { Know Your Academic Program }}$}

During the ninth week of the semester, an exercise called "Know Your Academic Program", aka, " 9 th Week Issues" is used to introduce the students to some university web resources for academic programs. This exercise is also used to increase the student's awareness of program and degree requirements, academic advising issues, and university policy with regard to common academic rules such as late drop of courses and final exam conflicts. An instructional computer lab is used in this team exercise which has a team component and an individual component. 


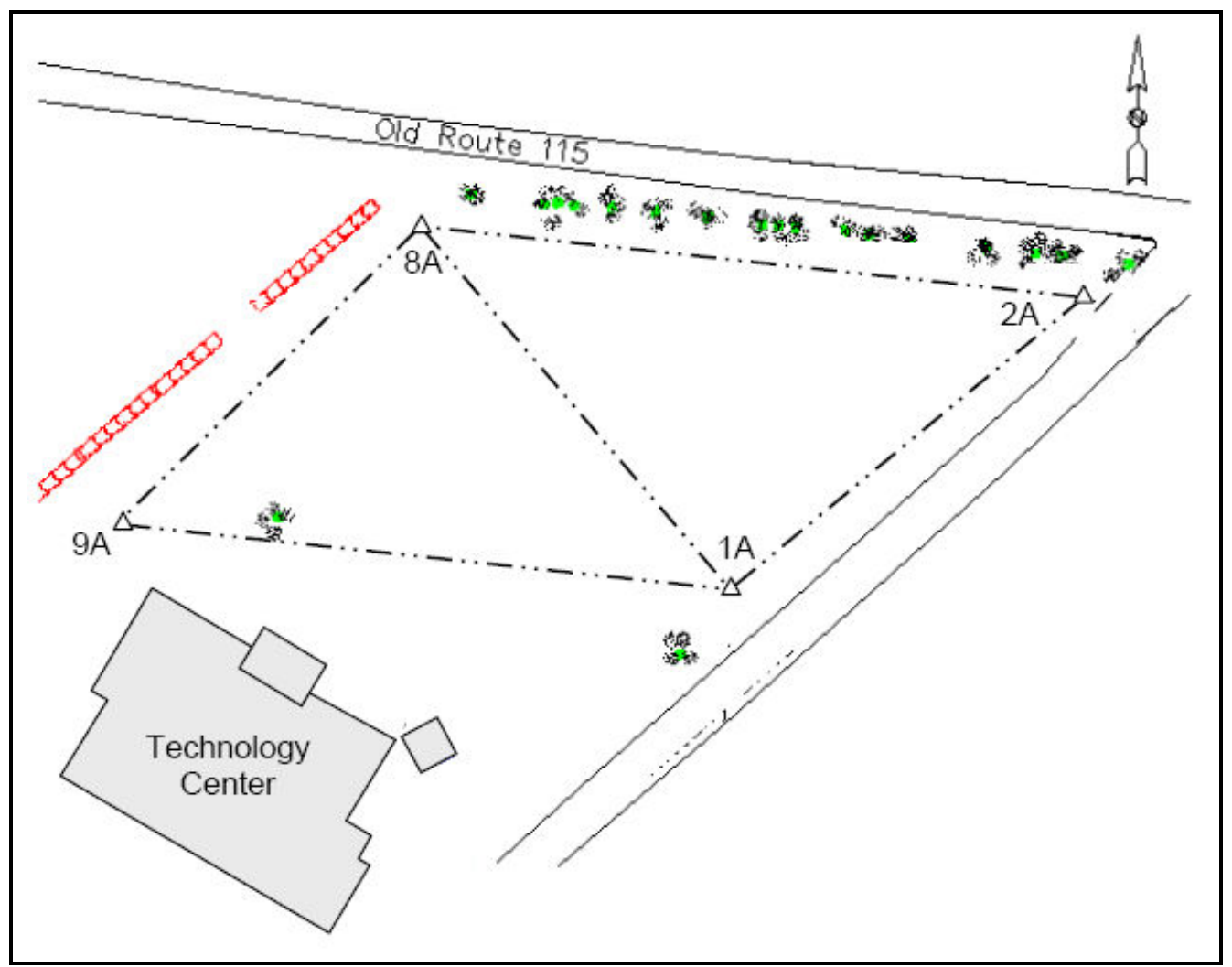

Figure 2. Polygon traverse (1A-2A-8A-9A-1A) used for the parcel measurement exercise.

In the team component, students are required to complete a set of questions regarding their academic program and course requirements. Such general program questions require the students to understand general education courses versus major requirement courses, number of dropcredits allowed, specific program graduation requirements, the appropriate sequence of courses in mathematics and physics, and other program related issues. The students become familiar with the university web sites that provide information to help them plan and complete their education according to university requirements. After some teamwork, a class discussion is used to clarifying why certain courses should be scheduled over others, or why one student's schedule will differ from another even when enrolled in the same major with the same semester standing.

In the individual exercise, each team member is required to prepare a course schedule for the next semester. This is their first attempt at creating a semester schedule on their own. Team members help each other complete their schedules with the assistance of the web resources. The professor acts as a group academic advisor. The exercise is delivered in the fall semester, two weeks prior to the time when freshman registration begins for the following semester. The exercise is generally very successful. In addition to building community, the dynamics of having a group of students all in one place, all in the same major, asking relevant questions in a group, is very effective in communicating the importance of good academic information and advising. All students are required to discuss the class schedule with their academic advisors during the following week. This starts them in the habit of seeking scheduling advice prior to registration. 


\section{Effect of the FYS on Retention}

As a measure of the FYS effect on retention rates, enrollment records for students in the surveying program were evaluated for the period from Fall 1994 through Fall 2007. The fouryear period from 1994 to 1997 is a population sample of students who did not experience the first-year seminar. The records show that 63 students are in this sample and 34 of them stayed in the program, returning the second year. The nine-year period covering Fall 1998 to 2006 (minus 2000 and 2004) is a population sample of students who did experience the first-year seminar. Data from 2000 and 2004 were not used in this group because the seminar course during those years was taught by a faculty person using a format different than that described in this paper. Records show that this second sample contains 58 students, of which 44 returned to the program the following fall semester. Table 2 summarizes the annual retention data.

For this study, retention is defined as the percentage of first-year students enrolled in the surveying program during their first-year Fall semester who return as enrolled surveying students for their second-year Fall semester. In the pool of students, all surveying students classified as first or second semester during a given first-year, Fall semester were counted. In most cases, the second semester classification students were true first-year surveying students who had advanced standing because of advanced placement credits or a small number of transfer credits from another institution.

Annual retention rates shown in Table 2 imply that retention has improved since 1999. The overall average retention rate prior to the implementation of the first-year seminar, based upon the population sample, is $54.0 \%$, while the overall rate after implementation is $75.9 \%$.

Table 2. Annual data for the two population samples

\begin{tabular}{cccc}
\hline Years without First-Year Seminar & & \\
Year & $\begin{array}{c}\text { Number of first-year } \\
\text { students Fall } \\
\text { semester }\end{array}$ & $\begin{array}{c}\text { Number of returning } \\
\text { students the following } \\
\text { Fall semester }\end{array}$ & Retention (\%) \\
\hline 1994 & 9 & 4 & 44.4 \\
1995 & 12 & 5 & 41.7 \\
1996 & 26 & 17 & 65.4 \\
1997 & 16 & 8 & 50.0 \\
\hline Total/Proportion & 63 & 34 & 54.0 \\
\hline Years with First-Year Seminar & 10 & & 80.0 \\
\hline 1998 & 9 & 8 & 77.8 \\
1999 & 10 & 7 & 70.0 \\
2001 & 8 & 7 & 75.0 \\
2002 & 4 & 6 & 100.0 \\
2003 & 9 & 4 & 77.8 \\
2005 & 8 & 7 & 62.5 \\
\hline 2006 & 58 & 5 & 75.9 \\
\hline Total/Proportion & & 44 & \\
\hline
\end{tabular}


The retention rates can be compared statistically by looking at the differences between the two average proportions. Devore ${ }^{1}$ presents a hypothesis testing procedure for comparing population proportions and it is used here to statistically test the results of the before and after retention rates. Table 3 establishes the statistical characteristics of the two population proportions.

Table 3. Statistical characteristics of the two population samples needed for hypothesis testing.

\begin{tabular}{lcc}
\hline \multirow{2}{*}{ Characteristic } & \multicolumn{2}{c}{ First-Year Students } \\
\cline { 2 - 3 } & Not taking FYS & Taking FYS \\
\hline Number of first-year students fall semester & $m=63$ & $n=58$ \\
Number returning the following fall semester & $x=34$ & $y=44$ \\
Sample proportion & $\hat{p}_{1}=0.540$ & $\hat{p}_{2}=0.759$ \\
\hline
\end{tabular}

If $p_{1}$ and $p_{2}$ represent the two population proportions, the hypotheses become

Null hypothesis, $H_{o}: p_{1}-p_{2}=0$ (There is no difference in the two population proportions.)

Alternative hypothesis, $H_{a}: p_{1}-p_{2} \neq 0$ ( $H_{\mathrm{o}}$ must be rejected.)

The test statistic value is: $z=\frac{\hat{p}_{1}-\hat{p}_{2}}{\sqrt{\hat{p} \hat{q}(1 / m+1 / n)}}$

The estimate of $p$ is: $\hat{p}=\frac{x+y}{m+n}=\frac{35+44}{63+58}=0.645$

Also $\hat{q}=(1-\hat{p})=(1-0.645)=0.355$

This is a two-tailed test, so at the level $0.05, H_{0}$ should be rejected if: $z \geq z_{0.025}$ or $z \leq-z_{0.025}$. From a chart of standard normal curve areas, $z_{0.025}=1.96$. The test statistic is computed as

$$
z=\frac{0.540-0.759}{\sqrt{(0.645)(0.355)(1 / 63+1 / 58)}}=-2.52
$$

Since $z(-2.52) \leq-z_{0.025}(-1.96)$, Ho must be rejected.

As a matter of interest, the $P$-value for this two-tailed $z$ test is also computed. Using the standard normal curve areas chart, $\Phi(2.52)=0.9941$. The $P$-value is computed as

$P$-value $=2[1-\Phi(2.52)]=2[1-0.9941]=0.0118$

Therefore, $H_{\mathrm{o}}$ must be rejected up to a level of $98.8 \%$. 
The result of this statistical test provides strong evidence that the difference in the two retention rates is statistically significant and it is probably very safe to state that the addition of the first-year seminar to the surveying program has had a positive effect on retention.

\section{Summary and Conclusion}

From this study, it is clear that the first-year seminar has a significant impact on retention of first-year students in the surveying program. Reasons for the success are attributed to several elements of the course, however, the most critical elements are probably related to (1) increasing interaction levels with other students in their major through team exercises (building friendships); (2) multiple sessions on review of fundamental surveying calculations that directly support skills in the mathematics and elementary surveying classes, (3) awareness of academic survival resources, especially tutoring, the learning center, and counseling, and (4) seminars presented by outside professionals that expose the first-year students to real world surveying activities and opportunities in the profession. Hypothesis testing was used to validate this study, and the testing shows that with $95 \%$ confidence the retention rate of first-year surveying students has increased since the addition of the first-year seminar to the surveying curriculum.

\section{Bibliography}

1. Devore, J. L., 2000. Probability and Statistics for Engineering and the Sciences, $5^{\text {th }}$ ed., Duxbury Thompson Learning, Pacific Grove, CA ISBN 0-534-37281-2214

2. Landis, R. and M. Roden, 1996. "Community Building - The Name Game," Success 101: A Forum for the Sharing of Ideas, Issue \#1, Spring 1996, Discovery Press (www.discovery-press.com).

3. Mendenhall, W. and T. Sincich, 1992. Statistics for Engineering and the Sciences, $3^{\text {rd }}$ ed., Dellen Publishing, San Francisco, CA ISBN 0-02-380-552-8.

4. Seybert, T. A., C. D. Ghilani, and B. J. Naberezny, 2000. "Enhancing the First-Semester Experience in Surveying," Journal of Surveying and Land Information Systems, Vol. 60, No. 3, pp. 183-189.

5. Seybert, T. A., 2002. "Building Community and Team Skills in a First-Year Seminar," Proceedings of the 2002 American Society for Engineering Education Zone I Conference, United States Military Academy, West Point, New York. 